\title{
PENGEMBANGAN INSTRUMEN EVALUASI UJI KOMPETENSI KEAHLIAN (UKK) ADMINISTRASI PERKANTORAN DI SMK
}

\author{
${ }^{1)}$ Suranto, ${ }^{2}$ Mubyadi, ${ }^{3)}$ Djemari Mardapi \\ ${ }^{1,2)}$ Fakultas Ekonomi Universitas Negeri Yogyakarta, \\ ${ }^{3}$ Fakultas Teknik Universitas Negeri Yogyakarta \\ ${ }^{1)}$ suranto@uny.ac.id, ${ }^{2)}$ muhyadi@uny.ac.id, ${ }^{3)}$ djemarimardapi@gmail.com
}

\begin{abstract}
Abstrak
Penelitian ini bertujuan mengembangkan instrumen yang cocok untuk melakukan evaluasi penyelenggaraan kegiatan UKK administrasi perkantoran di Sekolah Menengah Kejuruan (SMK). Penelitian pengembangan ini mencakup empat tahapan utama, yaitu tahap pendahuluan, tahap perencanaan dan pengembangan, tahap uji coba evaluasi dan revisi, serta tahap implementasi. Teknik pengumpulan data penelitian ini menggunakan teknik focus group discussion, angket/kuesioner, wawancara, observasi, dan studi dokumen. Analisis data dengan responden siswa menggunakan program Lisrel 8.51 dan data dengan responden guru dianalisis menggunakan SPSS 17.00 for Windows. Hasil penelitian ini sebagai berikut: (1) komponen penyelenggaraan UKK mencakup: (a) kolaborasi sekolah dengan asosiasi profesi dan DU/DI; (b) kinerja asesor; (c) sarana prasarana penunjang UKK; (d) sikap siswa terhadap UKK; (e) informasi capaian kompetensi siswa; dan (f) pengakuan legal asosiasi profesi dan DU/DI. (2) hasil pengujian menunjukkan: (a) instrumen dengan responden siswa berdasarkan data uji coba pada tahap implementasi, seluruh instrumen valid, reliabel, dan memenuhi syarat sebagai model yang fit; (b) instrumen dengan responden guru pada tahap implementasi menunjukkan seluruh butir instrumen memiliki nilai validitas $>0,30$ dan memenuhi kriteria $K M O>0,50$ serta koefisien reliabilitas $\alpha>0,70$.
\end{abstract}

Kata kunci: pengembangan, instrumen evaluasi, uji kompetensi keablian

\section{DEVELOPING AN EVALUATION INSTRUMENTS OF THE OFFICE ADMINISTRATION EXPERTISE COMPETENCY TEST IN VOCATIONAL HIGH SCHOOLS}

\author{
${ }^{1)}$ Suranto, ${ }^{2)}$ Mubyadi, ${ }^{3)}$ Djemari Mardapi \\ ${ }^{1,2)}$ Fakultas Ekonomi Universitas Negeri Yogyakarta, \\ ${ }^{3}$ Fakultas Teknik Universitas Negeri Yogyakarta \\ ${ }^{1)}$ suranto@uny.ac.id, ${ }^{2}$ muhyadi@uny.ac.id, ${ }^{3)}$ djemarimardapi@gmail.com
}

\begin{abstract}
This study aims to develop an evaluation instruments which is appropriate to evaluate the implementation of the Expertise Competency Test (ECT) for the Office Administration Expertise in vocational high schools (VHSs). This developmental research includes four major stages, namely the preliminary stage, the planning and development stage, the trial stage for evaluation and revision, as well as the implementation stage. For the data collection techniques, this study used focus group discussion, questionnaire, interview, observation, and document study. The data analysis for the students' responds was carried out using Lisrel Program version 8.51., while that for the teachers' responds was carried out using SPSS version 17.00 for Windows. The results of the study are as follows. 1) the components of the ECT activities include: (a) the collaboration of the schools and professional associations and the Business Sector/Industrial Sector (BS/IS); (b) the assessors' performances; (c) infrastructure facilities supporting the ECT; (d) students' attitudes towards the ECT; (e) the information about the students' attainments, and (f) the legal recognition from professional associations and the Business Sector/Industrial Sector or the BS/IS. 2) The study showed that: (a) based on the tryout data in the implementation stage, all items in the instrument with student respondents were valid, reliable, and qualified as a fit model; (b) on the implementation stage, all items in the instrument with teacher respondents had the validity value $>$ 0.3 and, therefore, met the criteria of $K M O>0.5$ and the coefficient of reliability $\alpha>0.70$.
\end{abstract}

Keywords: development, evaluation instrument, expertise competency test 


\section{Pendahuluan}

Sekolah Menengah Kejuruan (SMK) dirancang untuk menyiapkan peserta didik atau lulusan yang siap memasuki dunia kerja dan memiliki kompetensi di bidang kejuruan. Menurut Rupert Evans (Djojonegoro, 1998, p.33) pendidikan kejuruan ialah bagian dari sistem pendidikan yang mempersiapkan seseorang agar lebih mampu bekerja pada satu bidang pekerjaan. Salah satu upaya untuk menghasilkan lulusan yang memiliki kompetensi unggul, pemerintah melaksanakan kegiatan Uji Kompetensi Keahlian (UKK) dengan menerapkan sistem pengujian kompetensi atau "competency test" yang dilakukan untuk komponen mata pelajaran produktif dalam bentuk ujian praktik dan tertulis secara komprehensif-integratif. Mata pelajaran produktif yang diujikan pada UKK Administrasi Perkantoran mencakup: mengetik kecepatan, membuat surat, menangani arsip, mengelola kas kecil, membuat agenda kegiatan pimpinan, mengelola data dan informasi, menerima dan melakukan panggilan telepon, presentasi, menangani perjalanan bisnis, dan membuat notula rapat.

Pada hakikatnya UKK Administrasi Perkantoran adalah kegiatan yang bertujuan mengumpulkan data untuk mengukur penguasaan kompetensi siswa di bidang administrasi perkantoran. Kegiatan UKK terdiri dari dua kategori, yakni: (1) Uji Teori Kejuruan (UTK) dimaksudkan untuk menguji aspek teori-teori yang berbasis pada kompetensi keahlian administrasi perkantoran, nilai diakumulasikan dengan nilai rapor; (2) Uji Praktik Kejuruan (UPK) ialah mata uji untuk aspek praktik program keahlian yang melibatkan pihak eksternal (Dunia Kerja dan Industri). Nilai UPK menjadi dasar penerbitan sertifikat kompetensi.

Pelibatan secara aktif pihak eksternal sebagai asessor merupakan komitmen sekolah untuk dievaluasi oleh pihak eksternal guna mengkondisikan agar cakupan pembelajaran di SMK mengarah kepada kompetensi yang dituntut oleh dunia kerja. Selain itu, kegiatan UKK dengan melibatkan pihak eksternal, pada hakikatnya adalah sebuah pengakuan dari dunia kerja terhadap kompetensi siswa SMK. Menurut Uwe Schippers \& Patriana (Sigalingging, 2009, p.4) seorang lulusan SMK dianggap memiliki kompetensi bila ia telah memiliki kualifikasi kejuruan (kompetensi profesi), kualifikasi kejuruan penunjang, kualifikasi interdisipliner, kualifikasi operasional, dan kualifikasi kepribadian (personalitas).

Kegiatan UKK memiliki makna penting bagi sekolah kejuruan yang berusaha mempersiapkan lulusannya memasuki dunia kerja. Dalam Surat Edaran Direktorat Jenderal Manajemen Pendidikan Dasar dan Menengah Nomor: 351/C.C5/MN/2007 (Surat Edaran, 2007) menguatkan posisi pentingnya UKK bagi siswa SMK, karena nilai kelulusan UKK menjadi pertimbangan kelulusan peserta ujian nasional SMK.

Direktorat Pembinaan SMK (2011, pp.2-4) menguraikan komponen-komponen yang berpengaruh terhadap kualitas penyelenggaraan ujian praktik kejuruan, mencakup: (1) tempat penyelenggaraan ujian praktik kejuruan, (2) kerja sama penyelenggara tingkat satuan pendidikan dengan dunia usaha/industri/asosiasi profesi/institusi mitra, (3) sarana prasarana bahan, peralatan, dan alat penunjang ujian praktik kejuruan, (4) penguji atau asesor dari dunia usaha/industri/asosiasi profesi/guru sesuai kriteria yang telah ditetapkan, (5) peserta uji atau siswa, (6) hasil ujian praktik kejuruan berupa informasi capaian kompetensi siswa, dan (7) sertifikat yang ditandatangani oleh pihak eksternal.

Kolaborasi atau kerja sama penyelenggara UKK pada satuan pendidikan dengan dunia usaha/industri/asosiasi profesi/institusi mitra, pada hakikatnya pihak sekolah ingin memperoleh informasi dari dunia kerja mengenai standar kompetensi kerja yang dibutuhkan oleh pasar kerja. Berdasarkan standar kompetensi tersebut, maka sekolah menyusun kurikulum yang relevan. Selanjutnya kurikulum diimplementasikan dalam proses pembelajaran. Untuk mengetahui keberhasilan pembelajaran, dilakukan uji kompetensi. Dengan demikian, materi uji kompetensi juga harus sesuai dengan cakup- 
an SKL serta materi pembelajaran. Dengan demikian kolaborasi dalam menyiapkan perangkat UKK, antara sekolah dengan asosiasi profesi dan DU/DI yang diwakili oleh para asesor eksternal, perlu mempertimbangkan SKL pada sekolah yang bersangkutan.

Kualifikasi asesor sesuai dengan tujuan UKK juga perlu diperhatikan secara sungguh-sungguh. Asesor dapat derasal dari asosiasi profesi, maupun dari pengguna lulusan, yaitu DU/DI. Hal ini disebabkan, secara rasional, pihak-pihak yang paling mengetahui perkembangan kompetensi terkini yang dibutuhkan oleh dunia kerja adalah para praktisi di lapangan, yaitu asosiasi profesi dan DU/DI. Begitu pula kesesuaian antara ketersediaan sarana dan prasarana UKK dengan kebutuhan, juga menentukan kualitas penyelenggaraan kegiatan UKK.

Produk penyelenggaraan UKK ialah informasi capaian kompetensi yang menjadi dasar pengambilan keputusan kelulusan siswa. Apabila siswa lulus, maka menjadi dasar bagi asesor eksternal dari asosiasi profesi atau DU/DI untuk menerbitkan sertifikat kompetensi, dan menjadi pertimbangan bagi sekolah terkait kelulusan siswa dari SMK untuk mendapatkan ijazah.

Idealnya, setiap kegiatan pendidikan perlu dievaluasi untuk mengetahui tingkat keberhasilan pelaksanaan kegiatan tersebut sesuai dengan tujuan yang diharapkan. Berangkat dari permasalahan tersebut, dirasa penting adanya pengembangan instrumen evaluasi penyelenggaraan kegiatan UKK. Hal ini disebabkan, kegiatan UKK adalah sebuah aktivitas pendidikan yang sangat strategis untuk mengungkap capaian kompetensi siswa. Diperlukan evaluasi untuk mengetahui tingkat keberhasilan penyelenggaraan kegiatan UKK tersebut, sehingga menghasilkan informasi yang dapat digunakan oleh pimpinan sekolah untuk memperbaiki pelaksanaan UKK pada masa-masa mendatang. Secara rasional, ketersediaan instrumen evaluasi akan memotivasi pimpinan sekolah untuk melakukan evaluasi.

Instrumen evaluasi yang dikembangkan dalam penelitian ini adalah instrumen yang digunakan untuk mengevaluasi penyelenggaraan kegiatan UKK Administrasi Perkantoran di SMK. Salah satu alasan yang melatarbelakangi pengembangan instrumen evaluasi ini adalah adanya tuntutan peningkatan kualitas penyelenggaraan UKK. Bahwa dunia usaha dan industri menuntut agar penyelenggaraan UKK dapat ditingkatkan kualitasnya sehingga mampu menilai kesesuaian capaian kompetensi siswa SMK dengan tuntutan dunia kerja. Agar diperoleh informasi yang berguna sebagai pertimbangan peningkatan kualitas penyelenggaraan UKK, maka pengembangan instrumen evaluasi dipandang sebagai upaya strategis.

Dalam beberapa literatur (Cullingford, 1997; Djemari Mardapi, September 2000; Ebel \& Frisbie, 1986; Johnson \& Christensen, 2008), dapat dirangkum beberapa keuntungan dari evaluasi yang diterapkan untuk berbagai kegiatan dan program pendidikan, yakni terciptanya sebuah metode untuk menilai apakah kegiatan yang diselenggarakan tersebut telah sesuai dengan keinginan semula, dapat digunakan untuk melihat kembali apakah suatu kegiatan telah dapat dilaksanakan sesuai dengan perencanaan dan mencapai hasil sesuai yang diharapkan, selanjutnya informasi yang diperoleh dari evaluasi digunakan untuk menentukan alternatif yang tepat dalam mengambil sebuah keputusan.

Evaluasi merupakan salah satu rangkaian kegiatan untuk meningkatkan kualitas, kinerja, maupun produktivitas suatu lembaga dalam melaksanakan kegiatan. Melalui evaluasi akan diperoleh informasi tentang sejauhmana suatu kegiatan dapat dilaksanakan, selanjutnya informasi ini digunakan untuk perbaikan kegiatan tersebut. Menurut Royse, Thyer, dan Padgett (2010, p. 12) evaluasi merupakan bagian dari proses manajerial yang diterapkan untuk memperoleh informasi sebagai acuan dalam pembuatan keputusan. Evaluasi bukan merupakan hal baru dalam kehidupan organisasi sebab evaluasi senantiasa mengiringi dinamika kehidupan organisasi. Fitzpatrick, Sanders, dan Worthen $(2011$, p. 5) mengatakan, "evaluation is not a new concept. In fact, people have been 
evaluating, or examining and judging things, since the beginning of human history".

Faktor yang cukup dominan dalam menentukan keberhasilan suatu kegiatan pendidikan adalah kualitas komponen-komponen yang ada pada program pendidikan itu sendiri. Menurut Cox (2006, p. 8), "the quality of an educational program is comparised of three elements, materials (and equipment), activities, and people". Berdasarkan pendapat tersebut dapat dipahami bahwa kualitas program pendidikan tergantung pada sarana dan prasarana pembelajaran, aktivitas tenaga kependidikan dan siswa dalam kegiatan pendidikan, serta semua personal yang terlibat dalam kegiatan itu.

Berbagai penelitian dan evaluasi tentang kegiatan pendidikan menguatkan pandangan tentang pentingnya informasi tingkat keberhasilan penyelenggaraan suatu kegiatan. Penelitian tersebut diantaranya dilakukan oleh Mizikaci (2007, p.12), menyimpulkan bahwa evaluasi untuk menge-tahui atau mendeteksi kualitas sebuah prog-ram pendidikan, berawal dari asumsi-asumsi tentang "kualitas" suatu program itu sendiri, meliputi: (a) quality as excellent: kualitas sebagai hal yang baik; (b) quality as zero errors: kualitas dengan eror nol; (c) quality as fitness for purposes: kualitas sebagai pemenuhan kebutuhan; (d) quality as transformation: kualitas sebagai perubahan; (e) quality as threshold: kualitas sebagai ambang batas; (f) quality as value for money: kualitas sebagai nilai untuk memperoleh uang; (g) quality as enhancement or improvement: kualitas sebagai peningkatan atau perbaikan.

Selanjutnya penelitian yang dilakukan oleh Crawford (2006, p. 28) menunjukkan adanya komitmen, bahwa untuk mengetahui berbagai hasil yang terkait dengan kegiatan, tidak cukup dengan mencermati hasil kegiatan itu. Langkah yang tidak kalah pentingnya adalah mengumpulkan informasi untuk menentukan atau mengetahui bahwa hasil itu benar-benar karena suatu kegiatan, dan bukan karena faktor lain di luar kegiatan. Sanders \& Sullins (2006, p. 1) menjelaskan, "program evaluation is the process of systematically determining the quality of a program and how it can be improved'. Esensi dari definisi tersebut bahwa evaluasi program adalah proses sistematis menentukan kualitas program dan upaya meningkatkan kualitas program tersebut. Terkait dengan hal-hal tersebut dalam penelitian ini bertujuan mengembangkan instrumen yang cocok untuk melakukan evaluasi penyelenggaraan kegiatan UKK administrasi perkantoran di Sekolah Menengah Kejuruan (SMK).

\section{Metode Penelitian}

Penelitian ini menggunakan metode Penelitian Pengembangan (Research and Development), ialah metode penelitian yang digunakan untuk menghasilkan produk tertentu, dan menguji keefektifan produk tersebut. Dalam penelitian ini produk yang dikembangkan ialah instrumen evaluasi penyelenggaraan kegiatan UKK administrasi perkantoran di SMK. Model pengembangan yang digunakan sebagai kajian pada penelitian dan pengembangan ini mengacu pada model Borg dan Gall dengan dilakukan teknik memodifikasi dari 10 langkah penelitian menjadi empat tahapan penelitian, yakni tahap pendahuluan, tahap perencanaan dan pengembangan, tahap uji coba, dan tahap implementasi.

Modifikasi langkah-langkah penelitian tersebut dirancang dan dilaksanakan untuk dapat mengembangkan instrumen evaluasi penyelenggaraan kegiatan UKK administrasi perkantoran di SMK. Disamping itu, modifikasi langkah-langkah penelitian juga menyesuaikan langkah-langkah pengembangan instrumen yang dikemukakan oleh Mardapi (2005, pp.16-21), yaitu: (1) berdasarkan teori-teori tentang konsep dari variabel yang hendak diukur, dirumuskan konstruk variabel, (2) dikembangkan dimensi dan indikator, (3) membuat kisi-kisi instrumen, (4) menetapkan besaran atau parameter, (5) menulis butir-butir instrumen, (6) proses validasi, (7) revisi, (8) uji coba di lapangan.

Subjek uji coba atau responden yang terlibat dalam penelitian ini terdiri dari pakar evaluasi, kepala sekolah atau wakil kepala sekolah sebagai representasi dari pimpinan sekolah, guru administrasi perkantor- 
an, dan siswa peserta kegiatan UKK KK Administrasi Perkantoran.

Instrumen yang digunakan dalam pengumpulan data, juga sekaligus merupakan instrumen evaluasi yang dikembangkan yaitu inventori dalam bentuk rating scale untuk penyelenggaraan UKK Administrasi Perkantoran di SMK.

Analisis data uji coba lapangan bertujuan untuk memperoleh bukti validitas konstruk dan reliabilitas instrumen, yaitu menentukan kesesuaian antara konstruk teori dengan hasil pengukuran di lapangan. Analisis uji coba lapangan dilakukan dengan teknik analisis faktor konfirmatori. Instrumen pengumpul data dengan responden siswa dianalisis dengan Second Order Confirmatory Factor Analysis $(C F A)$ program Lisrel 8.70, sedangkan instrumen pengumpul data dengan responden guru dianalisis dengan Exploratory Factor Analysis (EFA) menggunakan SPSS 17,00 for windows. Penentuan validitas butir instrumen dengan responden siswa menggunakan CFA didasarkan pada kriteria nilai muatan faktor $>0,3$ dan nilai $t>1,96$ untuk masing-masing butir instrumen. Hal ini sesuai dengan pendapat Hair (2010, p.119) "factor loadings $\pm 0,3$ to 0,4 are minimally acceptable.

Selain untuk menganalisis validitas butir instrumen, Lisrel digunakan juga untuk menguji kecocokan model pengukuran (fit model). Model instrumen yang dikembangkan dinyatakan cocok dengan data lapangan apabila sudah terpenuhi dua kriteria dari tiga kriteria yang menjadi ukuran kecocokan yaitu Root Mean Square Error of Approximation $($ RMSE $A)<0,08 ;$ Chi-Square yang diperoleh dari pengujian memiliki probabilitas lebih besar dari 0,05 ( $\mathrm{p}>0,05)$; dan Goodness of Fit Index $(G F I)>0,90$.

Validitas instrumen dengan responden guru dianalisis dengan analisis faktor menggunakan SPSS 17 for windows. Uji validitas dilakukan menggunakan Exploratory Faktor Analysis (EFA). Selain itu, EFA digunakan untuk mengetahui apakah suatu konstruk dapat dijelaskan oleh indikator-indikatornya. Apabila indikator-indikator dapat membentuk konstruk atau variabel, maka ditunjukkan dengan nilai loading factor yang tinggi (>
$0,3)$ berarti pengukuran sudah sesuai dengan data, dan nilai Kaiser Meyer Olkin (KMO) > 0,5 (Ghozali,2005, pp.29-31). Untuk mengetahui validitas instrumen ditentukan dengan nilai muatan faktor. Butir-butir yang terdapat dalam setiap faktor harus memiliki muatan lebih besar 0,3 (Nurosis, 1986, p.12). Untuk menetapkan reliabilitas konstruk, digunakan formula Cronbach's Alpha yaitu sekurang-kurangnya 0,7 .

\section{Hasil Penelitian dan Pembahasan}

\section{Hasil Penelitian Tahap Pendahuluan}

Data yang disajikan pada hasil penelitian tahap pendahuluan ini, diperoleh melalui proses pengumpulan informasi dan studi pendahuluan yang meliputi: observasi awal di berbagai SMK untuk identifikasi masalah riil di lapangan, kajian pustaka, kajian peraturan, dan kajian hasil penelitian terdahulu. Tahapan ini mempunyai dua tujuan utama yaitu: (1) menemukan dan menetapkan variasi jenis SMK, terkait dengan visi misi sekolah, sistem pendidikan, sistem pengelolaan, serta sarana dan prasarana yang tersedia; dan (2) menemukan dan menetapkan komponen-komponen penyelenggaraan kegiatan UKK yang menjadi penentu kualitas penyelenggaraan UKK Administrasi Perkantoran di SMK yang menjadi dasar penjabaran menjadi konstruk teoritik dan indikator instrumen evaluasi IE-UKK.

Hasil studi pendahuluan dengan observasi awal di berbagai SMK dan divalidasi melalui Focus Group Discusion (FGD) pimpinan sekolah dan para guru, ditetapkan empat variasi jenis SMK, yaitu (1) SMK pemerintah (SMK Negeri), (2) SMK berbasis agama Islam, (3) SMK berbasis agama nonIslam, dan (4) SMK swasta berbasis yayasan sosial/pendidikan.

Berdasarkan studi literatur Petunjuk teknis pelaksanaan ujian kompetensi keablian SMK tabun pelajaran 2010/2011 (Direktorat Pembinaan SMK, 2011, pp.2-4) dapat ditemukan komponen-komponen yang berpengaruh terhadap kualitas penyelenggaraan ujian praktik kejuruan, mencakup: (1) tempat penyelenggaraan ujian praktik kejuruan, (2) kerja sama penyelenggara tingkat satuan 
pendidikan dengan dunia usaha/industri/ asosiasi profesi/institusi mitra, (3) sarana prasarana bahan, peralatan, dan alat penunjang ujian praktik kejuruan, (4) penguji atau asesor dari dunia usaha/industri/asosiasi profesi/guru sesuai kriteria yang telah ditetapkan, (5) peserta uji atau siswa, (6) pengorganisasian UKK, (7) hasil ujian praktik kejuruanberupa informasi capaian kompetensi siswa, dan (8) sertifikat yang ditandatangani oleh pihak eksternal.

Berdasarkan penilaian dan validasi melalui Focus Group Discusion (FGD) pimpinan sekolah dan para guru, ditetapkan komponen-komponen penyelenggaraan kegiatan UKK yang menjadi penentu kualitas penyelenggaraan UKK Administrasi Perkantoran di SMK yang menjadi dasar penjabaran menjadi konstruk teoritik dan indikator instrumen IE-UKK, mencakup: (1) kolaborasi sekolah dengan asosiasi profesi atau DU/ DI; (2) kinerja asesor; (3) ketersediaan sarana dan prasarana penunjang UKK; (4) sikap siswa terhadap kegiatan UKK; (5) informasi capaian kompetensi siswa peserta uji kompetensi; dan (6) pengakuan legal dari pihak eksternal (asosiasi profesi atau DU/DI).

\section{Hasil Uji Coba}

\section{Keterbacaan Instrumen}

Uji keterbacaan instrumen didasarkan pada hasil validasi (penilaian) dari para ahli evaluasi, pemakai model evaluasi (kepala sekolah), guru kompetensi administrasi perkantoran, serta praktisi yang memberi masukan-masukan dalam rangka perbaikan instrumen. Penilaian terhadap keterbacaan instrumen diarahkan pada aspek: (1) kejelasan petunjuk instrumen, (2) kejelasan indikator kolaborasi sekolah dengan asosiasi profesi dan DU/DI, (3) kejelasan indikator kinerja asesor, (4) kejelasan indikator sarana dan prasarana penunjang UKK, (5) kejelasan indikator sikap siswa terhadap UKK, (6) kejelasan indikator ketersediaan informasi capaian kompetensi siswa, (7) kejelasan indikator pengakuan legal asosiasi profesi, (8) penggunaan bahasa Indonesia baku, (9) perumusan pernyataan yang komunikatif, (10) bentuk huruf, (11) ukuran huruf, dan (12) tanda baca. Adapun hasil penilaian dari tiga tahap uji coba terhadap keterbacaan instrumen disajikan pada Tabel 1.

Tabel 1. Rekapitulasi Hasil Uji Keterbacaan Instrumen Evaluasi UKK (IE-UKK)

\begin{tabular}{|c|c|c|c|c|c|c|c|c|c|c|c|c|c|c|}
\hline Tahap & Jumlah & & & & & & Rerat & Skor & & & & & & Rerata \\
\hline & responden & 1 & 2 & 3 & 4 & 5 & 6 & 7 & 8 & 9 & 10 & 11 & 12 & Total \\
\hline 1 & 20 & 3,80 & 3,80 & 3,85 & 3,80 & 3,40 & 4,00 & 3,90 & 3,90 & 3,40 & 4,00 & 3,90 & 3,90 & 3,81 \\
\hline 2 & 54 & 4,00 & 3,90 & 4,03 & 3,90 & 4,01 & 4,01 & 3,90 & 3,90 & 3,40 & 4,00 & 3,90 & 3,90 & 3,91 \\
\hline 3 & 65 & 4,03 & 3,95 & 3,93 & 3,93 & 4,01 & 4,01 & 4,01 & 3,98 & 4,45 & 3,85 & 3,97 & 3,90 & 3,92 \\
\hline
\end{tabular}

Penilaian keterbacaan instrumen menggunakan skala 5 , yaitu skor minimal 1 dan skor maksimal 5. Tabel 1 menunjukkan rerata skor total pada uji coba ke-3 adalah 3,92. Apabila dikonsultasikan dengan pedoman konversi data kuantitatif ke kualitatif, berada pada rerata skor $>3,4-4,2$ masuk dalam klasifikasi layak atau baik. Hal ini memberi indikasi bahwa tingkat keterbacaan instrumen yang dikembangkan ini dapat diklasifikasikan layak atau baik.

Hasil Pengujian Instrumen dengan Responden Siswa

Instrumen pengumpul data dengan responden siswa dianalisis dengan Second Order Confirmatory Factor Analysis (CFA) program Lisrel 8.70. Imam Ghozali (2005, p.157) mengatakan bahwa second order confirmatory digunakan apabila satu faktor laten memiliki beberapa indikator, dan indikatorindikator tersebut tidak langsung dapat diukur karena memerlukan indikator lagi. Penentuan validitas butir instrumen dengan responden siswa menggunakan CFA didasarkan pada kriteria nilai muatan faktor $>$ 0,3 dan nilai $\mathrm{t}>1,96$ untuk masing-masing butir instrumen. Apabila nilai alpha lebih besar dari $5 \%$ dan nilai t kurang dari $t_{\text {tabel }}$ yaitu sebesar 1,96 (pada diagram second order menunjukkan warna merah) berarti nomor butir yang bersangkutan masuk dalam kate- 
gori tidak valid dan harus di-drop. Sebaliknya apabila nilai $t$ lebih besar dari $t_{\text {tabel }}$ sebesar 1,96 (pada diagram second order menunjukkan warna hitam), maka nomor butir tersebut termasuk dalam kategori valid.

Selain untuk menganalisis validitas butir instrumen, Lisrel digunakan juga untuk menguji kecocokan model pengukuran (fit model). Sebuah model dikatakan cocok (fit) apabila model teoritis atau model hipotetik yang dikembangkan pada penelitian cocok (fit) didukung oleh data empirik (Imam Ghozali, 2005, pp.29-31).

Model hipotetik yang diuji secara empiris dalam penelitian ini adalah instrumen evaluasi uji kompetensi keahlian administrasi perkantoran, yang terdiri dari: (1) kolaborasi antara sekolah dengan asosiasi profesi dan DU/DI; (2) kinerja asesor; (3) sarana dan prasarana penunjang UKK; (4) sikap siswa terhadap UKK; (4) ketersediaan informasi capaian kompetensi siswa; dan (5) pengakuan legal asosiasi profesi atau DU/ DI. Model instrumen yang dikembangkan dinyatakan cocok dengan data lapangan apabila sudah terpenuhi dua kriteria dari tiga kriteria yang menjadi ukuran kecocokan yaitu Root Mean Square Error of Approximation
$($ RMSE $A)<0,08 ;$ Chi-Square yang diperoleh dari pengujian memiliki probabilitas lebih besar dari 0,05 ( $\mathrm{p}>0,05)$; dan Goodness of Fit Index $(G F I)>0,90$.

Hasil pengujian pada uji coba tahap operasional instrumen kolaborasi sekolah dengan asosiasi profesi dan DU/DI, menunjukkan bahwa untuk semua nomor butir instrumen kualitas kolaborasi sekolah dengan asosiasi profesi dan DU/DI memiliki muatan faktor di atas 0,3 dan nilai $t$ lebih besar dari 1,96 sehingga semua butir instrumen dalam kategori valid. Koefisien Alpha menunjukkan untuk aspek $1 \alpha=0,799$ dan aspek $2 \alpha=0,749 \quad(>0,7)$ sehingga instrumen pada kedua aspek tersebut reliabel. Pengujian instrumen dengan Second Order CFA menunjukkan bahwa dilihat dari tiga kriteria, yaitu Chi-Square dan $\mathrm{p}$ value, RMSEA, dan GFI maka model masuk dalam kategori fit, karena nilai Chi-Square $=28,26$ p-value $=0,078>0,05$ RMSEA $=0,067<0,08$ dan $\mathrm{GFI}=0,96>0,90$. Hal tersebut menunjukkan bahwa model pengukuran teoritis instrumen kualitas kolaborasi sekolah dengan asosiasi profesi atau DU/DI cocok (fit) dengan model yang diperoleh dari data empirik.

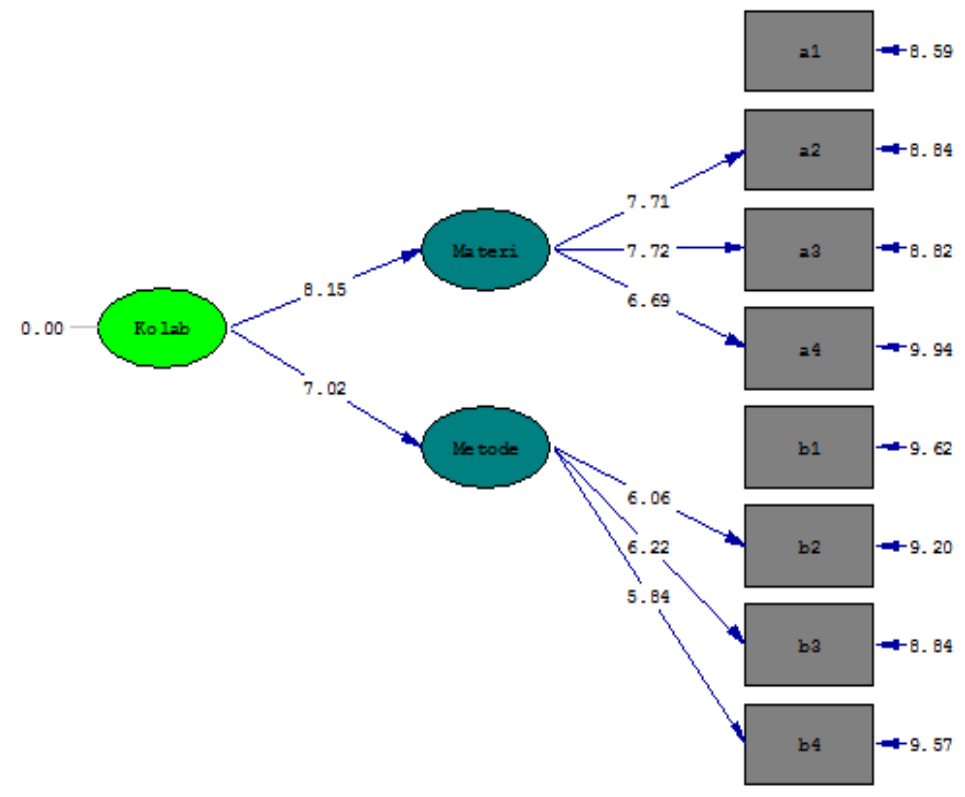

Chi-Square=28.26, df=19, P-value=0.07852, RMSEA=0.044

Gambar 1. Hasil Uji Coba Model Pengukuran (Konstruk) Kolaborasi Sekolah dengan DU/DI 
Konstruk variabel kinerja asesor terdiri atas empat faktor yaitu aspek penguasaan konsep UKK, keterkaitan profesi dengan materi yang diujikan, kemampuan penilaian, dan kemampuan memberikan masukan kepada sekolah. Hasil pengujian menunjukkan bahwa dari 25 butir instrumen kinerja asesor seluruhnya valid karena memiliki nilai muatan faktor di atas 0,3 dan nilai $t$ lebih besar dari 1,96. Dilihat dari koefisien Alpha, untuk ke empat aspek semuanya diperoleh angka lebih besar 0,7 sehingga instrumen kinerja asesor dikategorikan reliabel.
Dilihat dari kriteria kecocokan model pengukuran hipotetik dengan data empirik, menunjukkan nilai RMSE $A=0,032(<0,80)$ memenuhi syarat sebagai fit model, dan nilai $G F I=0,91(>0,90)$ juga telah memenuhi syarat sebagai fit model. Berdasarkan pengujian kecocokan model pengukuran tersebut dapat disimpulkan bahwa instrumen pengukuran kinerja asesor tersebut sudah dapat digunakan sebagai model pengukuran yang cocok untuk mengumpulkan data tentang kinerja asesor UKK.

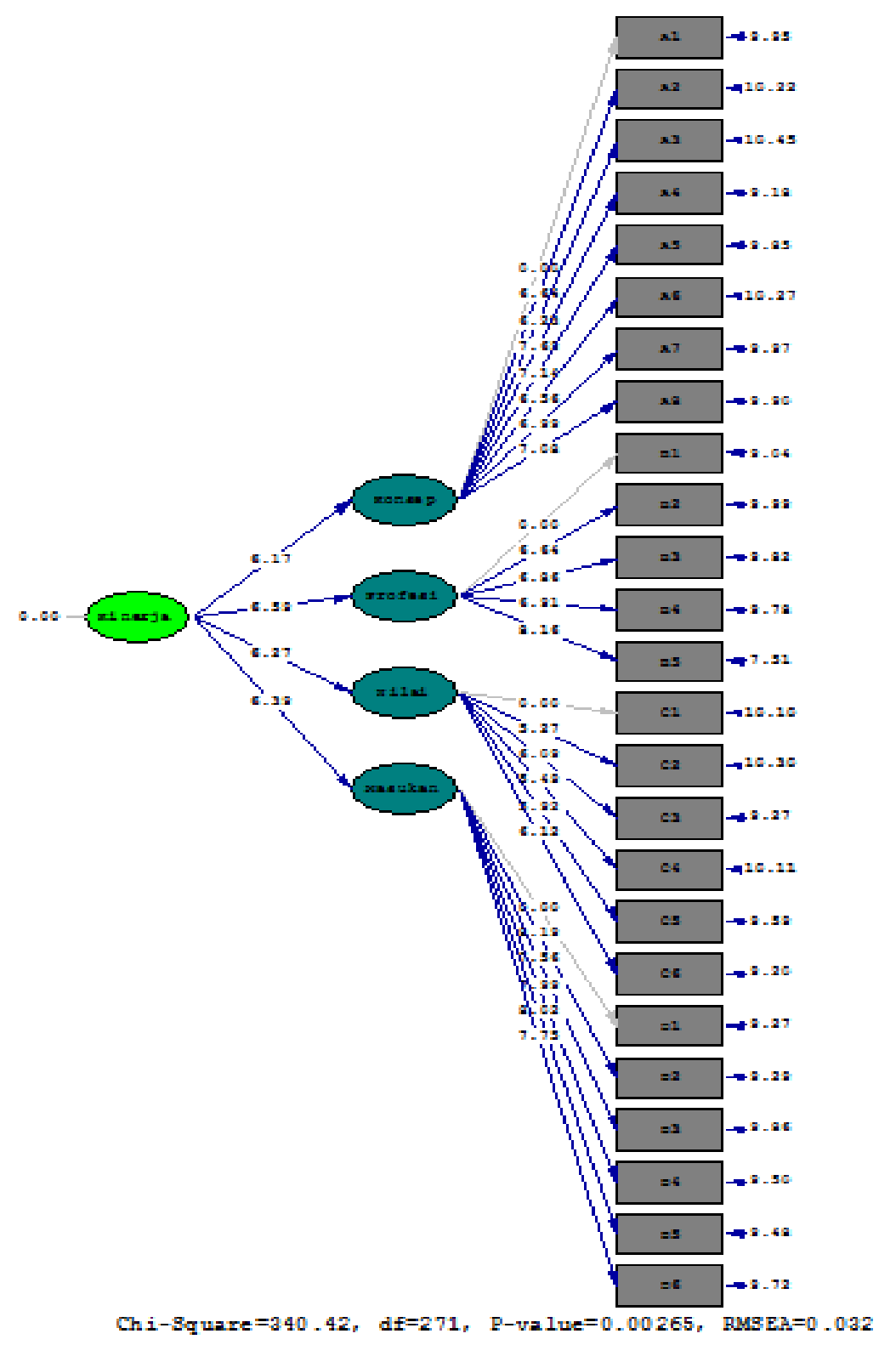

Gambar 2. Hasil Uji Coba Model Pengukuran (Konstruk) Kinerja Asesor 
Hasil pengujian instrumen sarana dan prasarana penunjang UKK, menunjukkan bahwa semua nomor butir instrumen sarana dan prasarana penunjang UKK memiliki muatan faktor di atas 0,3 dan nilai $t$ lebih besar dari 1,96 sehingga semua butir instrumen dalam kategori valid. Aspek tempat atau ruang ujian beserta kelengkapannya $\alpha$ $=0,797$, peralatan dan mesin kantor $\alpha=$ 0,795 , jumlah dan kualitas bahan $\alpha=0,793$ sehingga semua aspek instrumen dalam kategori reliabel.
Dari hasil pengujian ini dapat dikatakan bahwa dari 21 butir instrumen seluruhnya valid karena memiliki nilai muatan faktor $>0,3$ dan nilai $t>1,96$. Hasil pengujian menunjukkan nilai $\operatorname{RMSE} A=0,043$ $(<0,80)$ dan nilai $G F I=0,91(>0,90)$, artinya dua dari tiga kriteria sebagai model yang fit terpenuhi, maka instrumen tersebut sudah dapat digunakan sebagai model pengukuran yang cocok untuk mengumpulkan data tentang sarana dan prasarana penunjang UKK.

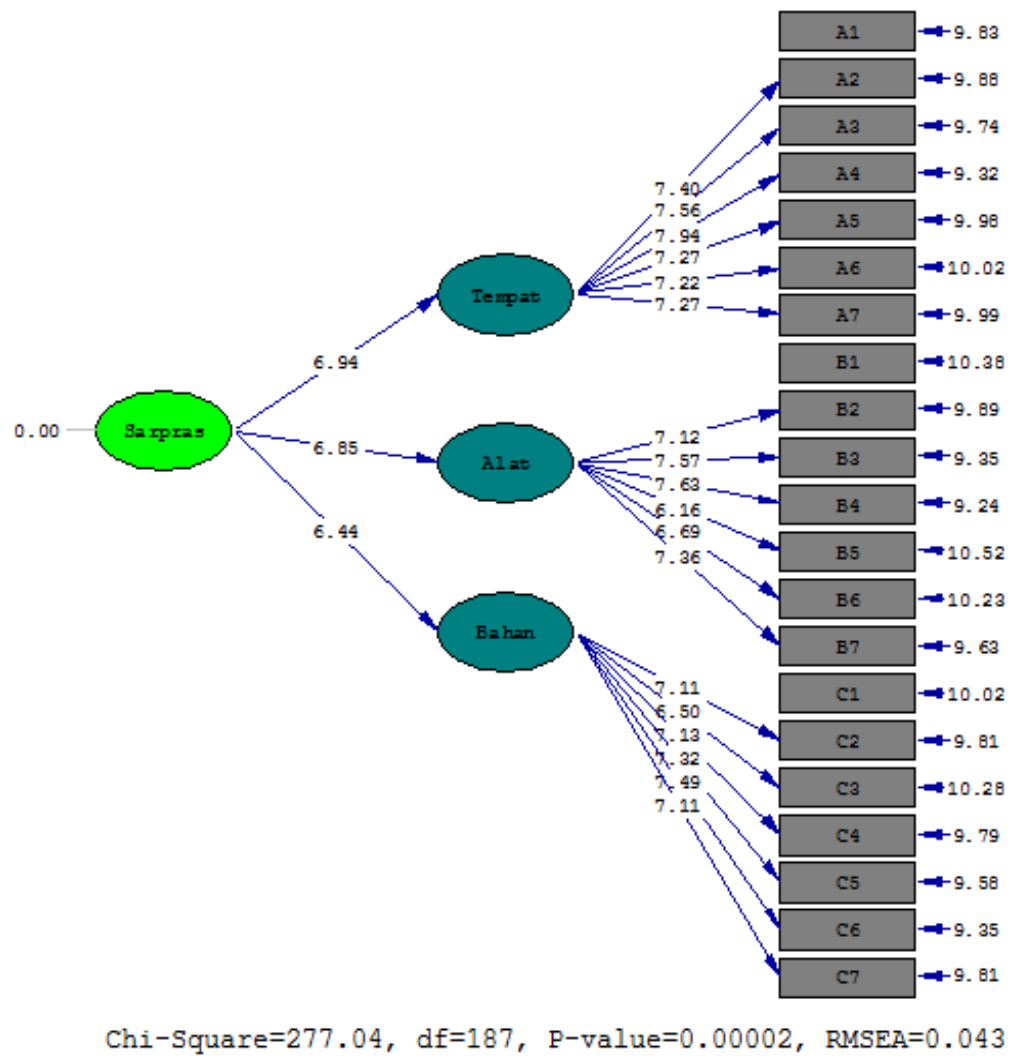

Gambar 3. Hasil Uji Coba Konstruk Sarana dan Prasarana Penunjang UKK

Hasil pengujian instrumen sikap siswa terhadap UKK, menunjukkan bahwa semua butir instrumen sikap siswa terhadap UKK memiliki muatan faktor di atas 0,3 dan nilai t lebih besar dari 1,96 sehingga semua butir instrumen dalam kategori valid. Pengujian reliabilitas menunjukkan bahwa pada aspek kognisi $\alpha=0,735$, aspek afeksi $\alpha=0,757$, dan aspek konasi $\alpha=737$, oleh karena $\alpha$ lebih besar 0,7 instrumen pada ketiga aspek tersebut dikategorikan reliabel Hasil pengujian ini, memberikan indikasi dari 13 butir instru- men seluruhnya valid karena memiliki nilai muatan faktor di atas 0,3 dan nilai t lebih besar dari 1,96.

Pengujian model Second Order CF $A$ menunjukkan bahwa dilihat dari ukuran RMSEA dan GFI maka model masuk dalam kategori fit, karena nilai RMSEA $=0,052<$ 0,08 dan $\mathrm{GFI}=0,91>0,90$. Hal tersebut menunjukkan bahwa model pengukuran teoretis instrumen sikap siswa terhadap UKK cocok (fit) dengan model yang diperoleh dari data empirik. 


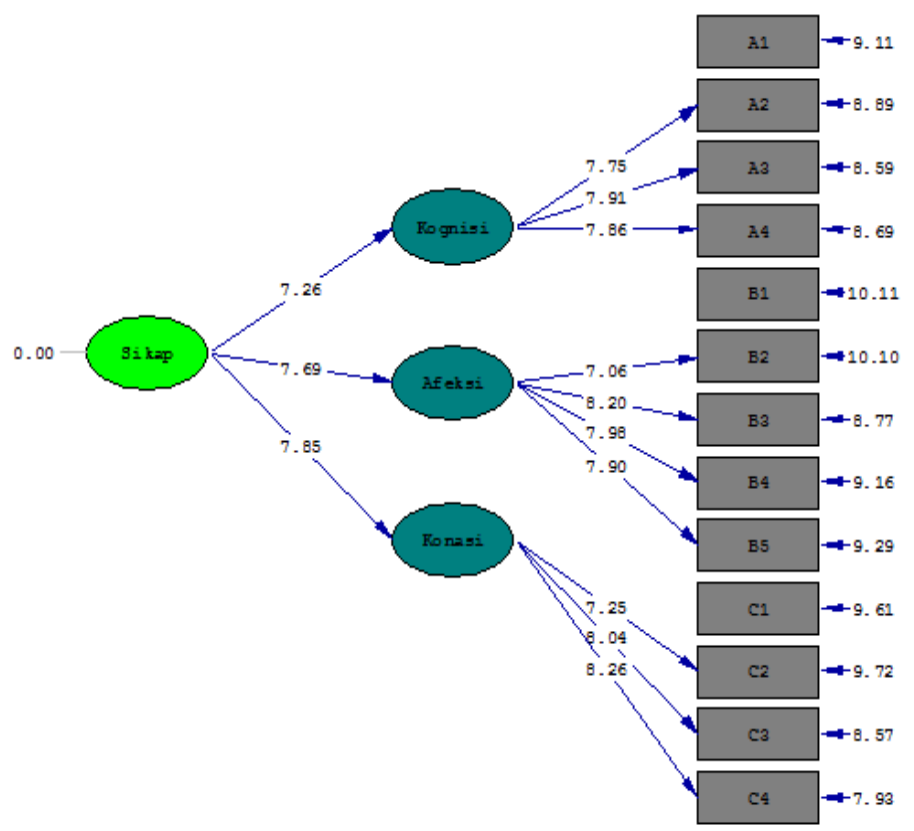

Chi-Square $=106.53, \mathrm{df}=63, \mathrm{P}-\mathrm{value}=0.00051, \mathrm{RMSEA}=0.052$

Gambar 4. Hasil Uji Coba Model Pengukuran (Konstruk) Sikap Siswa

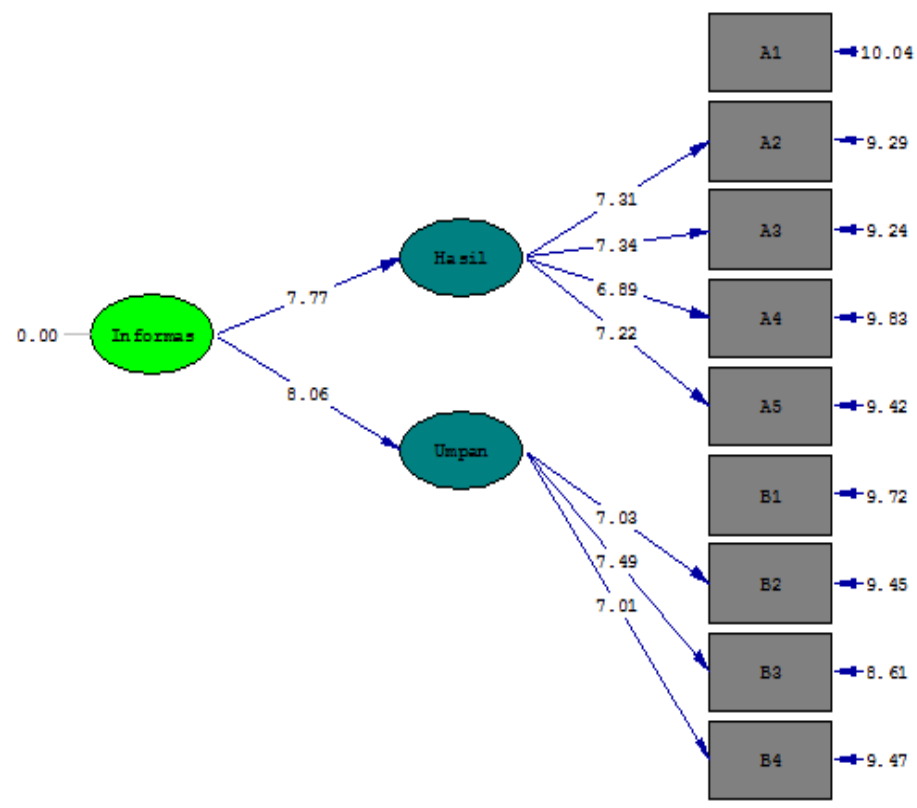

Chi-Square $=37.66, \mathrm{df}=26, \mathrm{P}$-value $=0.06516, \mathrm{RMSEA}=0.042$

Gambar 5. Hasil Uji Coba Konstruk Ketersediaan Informasi Capaian Kompetensi Siswa

Konstruk variabel informasi capaian kompetensi siswa mencakup dua aspek, yaitu: ketersediaan informasi hasil UKK dan umpan balik dari asesor untuk meningkatkan kompetensi siswa. Hasil pengujian instrumen ketersediaan informasi capaian kompetensi siswa, menunjukkan bahwa semua butir instrumen informasi capaian kompetensi siswa memiliki muatan faktor di atas 0,3 dan nilai $\mathrm{t}$ lebih besar dari 1,96 sehingga semua butir valid. Analisis reliabilitas pada aspek ketersediaan informasi hasil 
UKK $\alpha=0,781$ dan aspek umpan balik dari asesor untuk meningkatkan kompetensi siswa $\alpha=724$, oleh karena $\alpha$ lebih besar 0,7 maka instrumen pada ke dua aspek dikategorikan reliabel. Hasil pengujian ini mengindikasikan dari 9 butir instrumen informasi capaian kompetensi siswa seluruhnya valid karena memiliki nilai muatan faktor di atas 0,3 dan nilai $t$ lebih besar dari 1,96.

Pengujian model Second Order CFA menunjukkan bahwa dilihat dari ukuran $\mathrm{p}$ value, RMSEA dan GFI maka model masuk dalam kategori fit, karena nilai $\mathrm{p}$-value $=$ $0,06516>0,05, \quad$ RMSEA $=0,042<0,08$ dan GFI $=0,97>0,90$. Hal tersebut menunjukkan bahwa model pengukuran teoritis instrumen informasi capaian kompetensi siswa cocok (fit) dengan model yang diperoleh dari data empirik.

Instrumen pengakuan legal asosiasi profesi atau DU/DI mencakup dua aspek, yaitu penerbitan sertifikat kompetensi dan pengakuan pihak eksternal. Hasil pengujian instrumen pengakuan legal asosiasi profesi dan DU/DI memperlihatkan, bahwa semua butir instrumen memiliki muatan faktor di atas 0,3 dan nilai $t$ lebih besar dari 1,96 sehingga semua butir instrumen dalam kategori valid. Reliabilitas instrumen didasarkan pada kriteria $\alpha>0,7$ sedangkan hasil analisis menunjukkan aspek 1 mempunyai $\alpha=0,708$ dan aspek $2 \alpha=0,777$ sehingga instrumen pada kedua aspek tersebut reliabel.

Pengujian model Second Order CFA menunjukkan bahwa dilihat dari ukuran RMSEA dan GFI maka model masuk dalam kategori fit, karena nilai RMSEA $=0,054$ $<0,08$ dan $\mathrm{GFI}=0,97>0,90$. Hal tersebut menunjukkan bahwa model pengukuran teoretis instrumen pengakuan legal asosiasi profesi atau DU/DI cocok (fit) dengan model yang diperoleh dari data empirik. Oleh karena dua kriteria sebagai model yang fit terpenuhi, maka instrumen tersebut sudah dapat digunakan sebagai model pengukuran yang cocok untuk mengumpulkan data tentang pengakuan legal pihak eksternal, yaitu asosiasi profesi atau DU/DI.

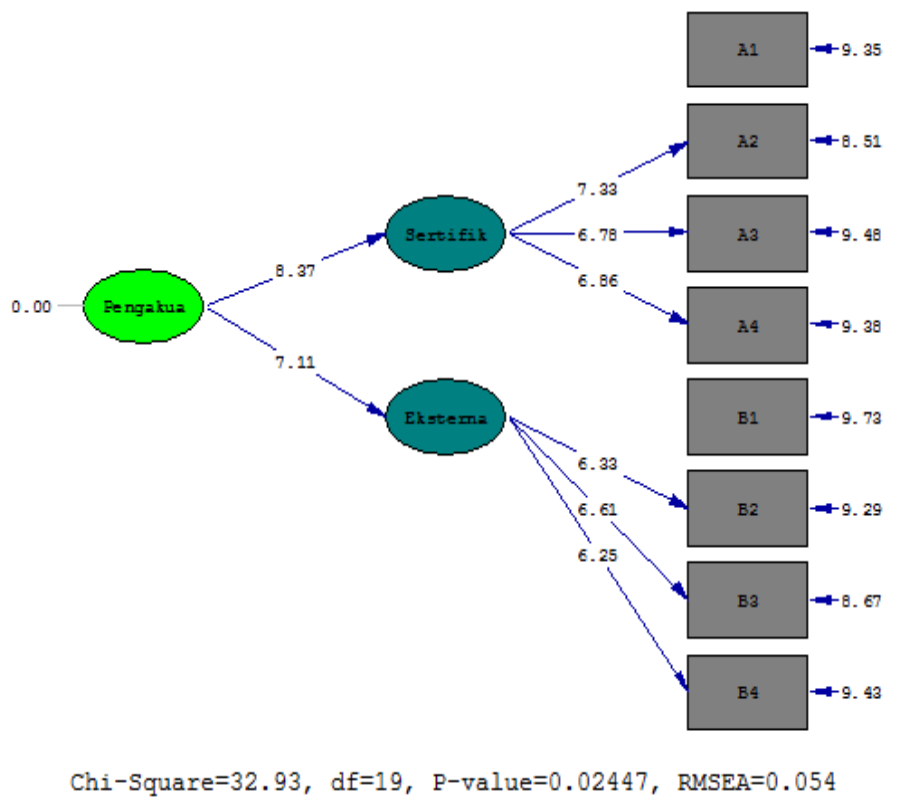

Gambar 6. Hasil Uji Coba Konstruk Pengakuan Legal Asosiasi Profesi dan DU/DI

Hasil Pengujian Instrumen dengan Responden Guru

Instrumen pengumpul data dengan responden guru dianalisis menggunakan Exploratory Factor Analysis (EFA) dengan bantuan program SPSS 17,00 for windows,
Analisis dengan EFA digunakan untuk mengetahui apakah konsep yang telah disusun berdasarkan kajian teori dan telah diuji secara empirik, didukung data atau tidak. Teknik ini juga dapat digunakan untuk mengestimasi validitas instrumen. 
Analisis EFA ini digunakan untuk mengetahui apakah suatu konstruk dapat dijelakan oleh indikator-indikatornya. Apabila indikator-indikator dapat membentuk konstruk atau variabel, maka ditunjukkan dengan nilai loading factor yang tinggi $(>0,3)$ berarti pengukuran sudah sesuai dengan data, dan nilai Kaiser Meyer Olkin (KMO) > 0,5 (Imam Ghozali, 2005, pp.29-31). Untuk mengetahui validitas instrumen ditentukan dengan nilai muatan faktor. Butir-butir yang terdapat dalam setiap faktor harus memiliki muatan lebih besar 0,3 (Nurosis, 1986, p.123).

Hasil pengujian instrumen kolaborasi sekolah dengan asosiasi profesi dan DU/DI menunjukkan besaran nilai Bartlett's Tes of Sphericity adalah 228,050 pada signifikansi 0,000 . Hal ini berarti pada aspek ini ada korelasi yang signifikan antarvariabel, dan hasil perhitungan $\mathrm{KMO}$ sebesar 0,670 sehingga kecukupan sampel terpenuhi.

Aspek kolaborasi sekolah dengan asosiasi profesi dan DU/DI pada uji coba tahap ketiga ini, dikembangkan dua faktor. Setelah dilakukan analisis, kedua faktor tersebut memiliki nilai eigen lebih dari satu, sehingga terpenuhi syarat sebagai faktor yang bisa dikembangkan.

Berdasarkan output rotated factor matrix ada dua faktor kolaborasi sekolah dengan asosiasi profesi dan DU/DI, yaitu faktor 1 penyusunan cakupan materi UKK dan faktor 2 kolaborasi penetapan metode penilaian. Selanjutnya disajikan sebaran butirbutir instrumen kolaborasi sekolah dengan asosiasi profesi dan DU/DI. Selanjutnya hasil uji coba ketiga terdapat delapan butir pernyataan untuk instrumen kolaborasi sekolah dengan asosiasi profesi dan DU/DI, karena satu butir nomor A5 didrop pada uji coba kedua. Kedelapan butir pernyataan tersebut masuk dalam faktor 1 dan 2 dengan total varian explained sebesar 61,631\%. Hal ini menunjukkan kedua faktor yang dikembangkan mampu mengukur variabel kolaborasi asosiasi profesi dan DU/DI sebesar 61,631\%.

Dilihat dari muatan faktor mengindikasikan untuk semua nomor butir innstrumen kolaborasi sekolah dengan asosiasi profesi dan DU/DI pada uji coba ketiga ini memiliki muatan faktor di atas 0,3 sehingga semua butir masuk kategori valid. Untuk reliabilitas, instrumen pada aspek penyusunan cakupan materi UKK $\alpha=0,891$ dan aspek kolaborasi penetapan metode penilaian $\alpha=$ 0,818 (lebih besar dari 0,7) sehingga disimpulkan instrumen pada kedua aspek tersebut reliabel.

Hasil pengujian instrumen kinerja asesor menunjukkan besaran nilai Bartlett's Tes of Sphericity adalah 937,417 pada signifikansi 0,000 . Hal ini berarti pada aspek kinerja asesor ini ada korelasi yang signifikan antarvariabel. Hasil perhitungan KMO sebesar 0,689 (lebih besar dari 0,5) sehingga kecukupan sampel terpenuhi.

Berdasarkan sebaran butir, terdapat 27 butir pernyataan atau pertanyaan untuk instrumen kinerja asesor, dan masuk dalam faktor 1, 2, 3, dan 4 dengan total varian explained sebesar 56,970\%. Hal ini menunjukkan ke empat faktor yang dikembangkan mampu mengukur variabel kinerja asesor sebesar $56,970 \%$.

Selanjutnya, dapat diketahui bahwa semua butir instrumen memiliki nilai validitas $>0,3$ dan memenuhi kriteria KaiserMeyer-Olkin Measure of Sampling Adequacy dengan muatan sebesar 0,689 $(>0,5)$. Reliabilitas pada aspek 1 mempunyai $\alpha=0,885$, aspek $2 \alpha=0,953$, aspek $3 \alpha=0,837$, dan aspek $4 \alpha=0,847(>0,7)$.

Instrumen sarana dan prasarana penunjang UKK mencakup tiga aspek, yaitu: tempat atau ruang ujian beserta kelengkapannya, peralatan dan mesin kantor, jumlah dan kualitas bahan. Hasil perhitungan menunjukkan besaran nilai Bartlett's Tes of Sphericity adalah 665,608 pada signifikansi 0,000 yang berarti pada aspek sarana dan prasarana penunjang UKK ini ada korelasi yang signifikan antarvariabel, dan hasil perhitungan $K M O$ sebesar 0,810 $(>0,5)$ sehingga kecukupan sampel terpenuhi.

Berdasarkan sebaran butir, terdapat 17 butir pernyataan atau pertanyaan untuk instrumen sarana dan prasarana penunjang UKK, dan masuk dalam faktor 1, 2, dan 3 dengan total varian explained sebesar 67,217\%. 
Hal ini menunjukkan ke tiga faktor yang dikembangkan mampu mengukur variabel sarana dan prasarana penunjang UKK sebesar 67,217\%.

Selanjutnya, dapat diketahui bahwa semua butir instrumen memiliki nilai validitas $>0,3$ dan memenuhi kriteria KaiserMeyer-Olkin Measure of Sampling Adequacy dengan muatan sebesar $0,810(>0,5)$. Untuk reliabilitas pada aspek 1 mempunyai $\alpha=$ 0,943 , aspek $2 \alpha=0,869$, dan aspek $3 \alpha=$ $0,916(>0,7)$.

Hasil pengujian instrumen informasi capaian kompetensi siswa menunjukkan besaran nilai Bartlett's Tes of Sphericity adalah 255,997 pada signifikansi 0,000. Hal ini berarti pada aspek ketersediaan informasi capaian kompetensi siswa ini ada korelasi yang signifikan antarvariabel, dan hasil perhitungan KMO sebesar 0,744 sehingga kecukupan sampel terpenuhi.

Analisis faktor aspek ketersediaan informasi capaian kompetensi menghasilkan dua faktor yang memiliki nilai eigen lebih dari satu. terdapat 9 butir pernyataan atau pertanyaan untuk instrumen ketersediaan informasi capaian kompetensi siswa, dan masuk dalam faktor 1 dan 2 dengan total varian explained sebesar $60,835 \%$. Hal ini menunjukkan kedua faktor yang dikembangkan mampu mengukur variabel ketersediaan informasi capaian kompetensi siswa sebesar $60,835 \%$.

Selanjutnya, dari hasil pengujian dapat diketahui bahwa semua butir instrumen memiliki nilai validitas $>0,3$ dan memenuhi kriteria Kaiser-Meyer-Olkin Measure of Sampling Adequacy dengan muatan sebesar 0,744 (> $0,5)$. Untuk reliabilitas pada aspek 1 mempunyai $\alpha=0,902$ dan aspek $2 \alpha=0,753(>0,7)$.

Hasil pengujian instrumen pengakuan legal asosiasi profesi dan DU/DI menunjukkan besaran nilai Bartlett's Tes of Sphericity adalah 182 pada signifikansi 0,000 yang berarti pada aspek pengakuan legal asosiasi profesi dan DU/DI ini ada korelasi yang signifikan antarvariabel, dan hasil perhitungan KMO sebesar 0,747 sehingga kecukupan sampel terpenuhi.
Berdasarkan output rotated factor matrix, ada dua faktor aspek ketersediaan informasi capaian kompetensi siswa, yaitu faktor 1 pengakuan pihak eksternal, dan faktor 2 penerbitan sertifikat kompetensi. Selanjutnya dilihat dari sebaran butir-butir instrumen pengakuan legal asosiasi profesi dan DU/ DI menjelaskan adanya tujuh butir pernyataan atau pertanyaan untuk instrumen pengakuan legal asosiasi profesi dan DU/DI dan masuk dalam faktor 1 dan 2 dengan total varian explained sebesar $65,724 \%$. Hal ini menunjukkan kedua faktor yang dikembangkan mampu mengukur variabel pengakuan legal asosiasi profesi dan DU/DI sebesar $65,724 \%$. Hasil pengujian validitas dan reliabilitas menunjukkan bahwa semua butir instrumen memiliki nilai validitas $>$ 0,3 dan memenuhi kriteria Kaiser-Meyer-Olkin Measure of Sampling Adequacy dengan muatan sebesar $0,747(>0,5)$. Untuk reliabilitas pada aspek 1 mempunyai $\alpha=0,876$ dan aspek 2 $\alpha=0,793(>0,7)$ memberi indikasi bahwa instrumen reliabel.

\section{Pembahasan}

Hasil analisis secara deskriptif terhadap tingkat keterbacaan instrumen menunjukkan bahwa pada uji coba tahap ke tiga rerata total mencapai 3,92. Hal ini memberikan indikasi bahwa tingkat keterbacaan instrumen evaluasi UKK berada pada predikat baik. Dengan demikian, validasi melalui proses pemeriksaan oleh pakar telah mengantarkan perumusan butir-butir instrumen sesuai dengan indikatornya. Mardapi (2005, pp. 15-20) mengatakan bahwa proses validasi, baik validasi teoritik maupun validasi empirik merupakan langkah yang penting. Validasi teoretik yaitu melalui pemeriksaan pakar untuk menelaah seberapa jauh dimensi merupakan jabaran yang tepat dari konstruk, seberapa jauh indikator merupakan jabaran yang tepat dari dimensi, dan seberapa jauh butir-butir instrumen yang dibuat secara tepat dapat mengukur indikator.

Sistem indikator dirancang untuk memberikan informasi akurat tentang berbagai kondisi dan memberi informasi bagaimana komponen-komponen yang akan dievaluasi 
menghasilkan efek secara keseluruhan. Konsep ini sejalan dengan pendapat Shavelson (2001, p.7) bahwa merancang indikator dapat dilakukan dengan langkah-langkah: conceptualize potential indicator, refine indicator poor, design alternative indicator system options, evaluate the options and begin developing or refining individual indicator.

Hasil pengujian instrumen kolaborasi sekolah dengan asosiasi profesi dan DU/ DI, menunjukkan bahwa berdasarkan data uji coba pada tahap implementasi, dari delapan butir instrumen seluruhnya valid karena memiliki nilai muatan faktor di atas 0,3 dan nilai $t$ lebih besar dari 1,96. Kedua aspek instrumen memiliki koefisien Alpha di atas 0,7 sehingga instrumen pada ke dua aspek tersebut reliabel. Nilai $p$-value $=0,0781(>0,05)$, nilai $R M S E A=0,044(<0,80)$ dan nilai $G F I=$ $0,97(>0,90)$ memenuhi syarat sebagai fit model. Hasil pengujian memberikan indikasi bahwa semua persyaratan sebagai model yang fit terpenuhi, dengan demikian instrumen pengukuran tersebut sudah dapat digunakan sebagai model pengukuran yang cocok untuk mengumpulkan data tentang kolaborasi sekolah dengan asosiasi profesi dan DU/DI.

Kolaborasi atau kerja sama penyelenggara UKK pada satuan pendidikan dengan dunia usaha/industri/asosiasi profesi/ institusi mitra, pada hakikatnya pihak sekolah ingin memperoleh informasi dari dunia kerja mengenai standar kompetensi kerja yang dibutuhkan oleh pasar kerja. Berdasarkan standar kompetensi tersebut, maka sekolah menyusun kurikulum yang relevan. Selanjutnya, kurikulum diimplementasikan dalam proses pembelajaran. Untuk mengetahui keberhasilan pembelajaran, dilakukan uji kompetensi. Dengan demikian, materi uji kompetensi juga harus sesuai dengan cakupan SKL serta materi pembelajaran.

Hasil pengujian instrumen kinerja asesor, menunjukkan bahwa dari 25 butir instrumen kinerja asesor seluruhnya valid karena memiliki nilai muatan faktor di atas 0,3 dan nilai t lebih besar dari 1,96. Kriteria kecocokan model pengukuran hipotetik dengan data empirik, menunjukkan nilai
RMSE $A=0,032 \quad(<0,80)$ memenuhi syarat sebagai fit model, dan nilai $G F I=0,91$ ( $>$ $0,90)$ juga telah memenuhi syarat sebagai fit model, dengan demikian instrumen pengukuran kinerja asesor tersebut sudah dapat digunakan sebagai model pengukuran yang cocok untuk mengumpulkan data tentang kinerja asesor UKK.

Kualifikasi asesor sesuai dengan tujuan UKK juga perlu diperhatikan secara sungguh-sungguh. Asesor dapat berasal dari asosiasi profesi, maupun dari pengguna lulusan, yaitu DU/DI. Hal ini disebabkan, secara rasional, pihak-pihak yang paling mengetahui perkembangan kompetensi terkini yang dibutuhkan oleh dunia kerja adalah para praktisi di lapangan, yaitu asosiasi profesi dan DU/DI

Hasil pengujian instrumen sarana prasarana penunjang UKK mengindikasikan dari 21 butir instrumen seluruhnya valid karena memiliki nilai muatan faktor $>0,3$ dan nilai $\mathrm{t}>1,96$. Hasil pengujian menunjukkan nilai $R M S E A=0,043(<0,80)$ dan nilai $G F I=0,91(>0,90)$, artinya dua dari tiga kriteria sebagai model yang fit terpenuhi, maka instrumen tersebut sudah dapat digunakan sebagai model pengukuran yang cocok untuk mengumpulkan data tentang sarana dan prasarana penunjang UKK.

Hasil pengujian instrumen sikap siswa terhadap UKK, menunjukkan bahwa semua butir instrumen sikap siswa terhadap UKK memiliki muatan faktor di atas 0,3 dan nilai t lebih besar dari 1,96 sehingga semua butir instrumen dalam kategori valid. Nilai RMS$E A=0,052(<0,80)$ dan nilai $G F I=0,91 \quad>$ $0,90)$ telah memenuhi kriteria sebagai fit model.

Hasil pengujian instrumen ketersediaan informasi capaian kompetensi siswa, mengindikasikan dari 9 butir instrumen informasi capaian kompetensi siswa seluruhnya valid karena memiliki nilai muatan faktor di atas 0,3 dan nilai $t$ lebih besar dari 1,96. Nilai $p$-value $=0,06516(>0,05)$, nilai RMSE $A=0,042(<0,80)$, dan nilai $G F I=0,97$ $(>0,90)$ memenuhi tiga kriteria sebagai fit model. 
Hasil pengujian instrumen pengakuan legal asosiasi profesi dan DU/DI memperlihatkan, dari 8 butir instrumen seluruhnya valid karena memiliki nilai muatan faktor di atas 0,3 dan nilai $t$ lebih besar dari 1,96. Nilai RMSE $A=0,054(<0,80)$ memenuhi syarat sebagai fit model, dan nilai GFI $=0,97(>0,90)$ juga telah memenuhi syarat sebagai fit model. Oleh karena dua kriteria sebagai model yang fit terpenuhi, maka instrumen tersebut sudah dapat digunakan sebagai model pengukuran yang cocok untuk mengumpulkan data tentang pengakuan legal pihak eksternal, yaitu asosiasi profesi atau DU/DI.

Hasil analisis statistik untuk menguji validitas dan reliabilitas instrumen telah memenuhi kriteria sebagai model instrumen yang valid dan riliabel. Kriteria validitas butir instrumen sesuai dengan pendapat Hair (2010, p. 119) "factor loadings $\pm 0,3$ to 0,4 are minimally acceptable. Pendapat senada dikemukakan Tabachnick (2007, p. 649) "as rule of thumb, only variables with factor loadings of .32 and above are interpreted". Hasil analisis validitas ini memberi makna penting, bahwa semua butir instrumen mampu mengukur apa yang seharusnya diukur.

Hasil-hasil statistik sebagai kriteria goodness of fit yang digunakan untuk menilai kecocokan model pengukuran instrumen dengan responden siswa yaitu p-value, Root Mean Square Error of Approximation (RMSE A) dan Goodness of Fit Index (GFI) menunjukkan kecocokan yang cukup baik antara model teoretis dengan data lapangan ketika instrumen diuji cobakan. Kecocokan model pengukuran tersebut ditentukan oleh sekurang-kurangnya terpenuhi dua dari tiga kriteria tersebut, sehingga instrumen tersebut sudah dapat digunakan sebagai model pengukuran yang cocok untuk mengumpulkan data tentang penyelenggaraan UKK Administrasi Perkantoran di SMK.

Hasil analisis fit model pada tahap ketiga (implementasi) dibandingkan dengan analisis uji coba tahap kedua, untuk nilai $p$ value mengalami peningkatan dari 0,0024 menjadi 0,078. Peningkatan tersebut memiliki makna penting, karena hasil penilaian tersebut telah mengubah klasifikasi yang semula terdapat dua kriteria fit, kemudian menjadi terpenuhi tiga kriteria sebagai model yang cocok (fit model). Peningkatan tersebut terjadi karena adanya perbedaan jumlah dan karakteristik responden. Pada uji coba kedua responden berjumlah 196 siswa, sedangkan uji coba tahap ketiga responden berjumlah 256 siswa.

Instrumen dengan responden guru dianalisis menggunakan Exploratory Factor Analysis (EFA) dengan bantuan program SPSS 17,00 for windows. Analisis EFA ini untuk menguji apakah suatu konstruk dapat dijelaskan oleh indikator-indikatornya. Apabila indikator dapat membentuk konstruk atau variabel, maka ditunjukkan dengan muatan faktor yang tinggi $(>0,3)$ berarti pengukuran sudah sesuai data, dan diharapkan nilai Kaiser-Meyer-Olkin Measure of Sampling (KMO) lebih besar dari 0,5. Sedangkan untuk memeriksa reliabilitas sebuah instrumen adalah dengan melihat nilai koefisien $A$ Ahba dari formula Cronbach's Alpha, yaitu sekurang-kurangnya 0,7 sebagai batas terendah.

Semua butir instrumen kolaborasi sekolah dengan asosiasi profesi dan DU/DI memiliki nilai validitas $>0,3$ (kecuali butir A5) dan memenuhi kriteria Kaiser-MeyerOlkin Measure of Sampling Adequacy dengan muatan sebesar 0,670 $(>0,5)$. Untuk reliabilitas pada aspek 1 mempunyai $\alpha=0,915$ dan aspek $2 \alpha=0,894(>0,7)$.

Instrumen kinerja asesor dapat diketahui bahwa semua butir instrumen memiliki nilai validitas $>0,3$ dan memenuhi kriteria Kaiser-Meyer-Olkin Measure of Sampling Adequacy dengan muatan sebesar 0,689 (> $0,5)$. Untuk reliabilitas pada aspek 1 mempunyai $\alpha=0,885$, aspek $2 \alpha=0,953$, aspek 3 $\alpha=0,837$, dan aspek $4 \alpha=0,847 \quad(>0,7)$.

Instrumen sarana dan prasarana penunjang UKK, dapat diketahui bahwa semua butir instrumen memiliki nilai validitas $>$ 0,3 dan memenuhi kriteria Kaiser-MeyerOlkin Measure of Sampling Adequacy dengan muatan sebesar $0,810(>0,5)$. Untuk reliabilitas pada aspek 1 mempunyai $\alpha=0,943$, aspek $2 \alpha=0,869$, dan aspek $3 \alpha=0,916(>0,7)$. 
Untuk instrumen informasi capaian kompetensi siswa, setelah dianalisis dapat diketahui bahwa semua butir instrumen memiliki nilai validitas $>0,3$ dan memenuhi kriteria Kaiser-Meyer-Olkin Measure of Sampling Adequacy dengan muatan sebesar 0,744 (> $0,5)$. Untuk reliabilitas pada aspek 1 mempunyai $\alpha=0,902$ dan aspek $2 \alpha=0,753(>0,7)$.

Hasil analisis instrumen pengakuan legal asosiasi profesi atau DU/DI, diketahui bahwa semua butir instrumen memiliki nilai validitas $>0,3$ dan memenuhi kriteria Kaiser-Meyer-Olkin Measure of Sampling Adequacy dengan muatan sebesar $0,747(>0,5)$. Untuk reliabilitas pada aspek 1 mempunyai $\alpha=$ 0,876 dan aspek $2 \alpha=0,793(>0,7)$ memberi indikasi bahwa instrumen reliabel.

Hasil pengujian menunjukkan bahwa muatan faktor untuk setiap butir instrumen cukup tinggi $(>0,3)$ dan nilai Kaiser-MeyerOlkin Measure of Sampling (KMO) lebih besar dari 0,5 , hal ini memberi indikasi bahwa indikator dapat membentuk konstruk atau variabel, berarti pengukuran sudah sesuai data. Selanjutnya hasil pengujian reliabilitas instrumen memperlihatkan nilai koefisien Alpha dari formula Cronbach's Alpha memenuhi sekurang-kurangnya 0,7 sebagai batas terendah, sehingga instrumen tersebut reliabel.

Hasil uji kuantitatif, baik untuk instrumen siswa yang dianalisis dengan second order confirmatory factor analysis ( $C F A$ ) maupun instrumen guru yang dianalisis dengan $E F A$ menunjukkan bahwa butir-butir instrumen yang dikembangkan merupakan butir yang valid dan instrumen tersebut reliabel. Selain itu, instrumen evaluasi IE-UKK merupakan model instrumen evaluasi yang sesuai atau cocok untuk mengevaluasi kualitas penyelenggaraan UKK Administrasi Perkantoran di SMK, karena model tersebut secara statistik didukung oleh data lapangan, baik dari segi model strukturalnya maupun dari segi model pengukurannya.

Didukung adanya panduan evaluasi yang cukup singkat tetapi lengkap akan mempermudah penerapan instrumen evaluasi IE-UKK. Sanders \& Sullins (2006, p.1) menjelaskan, "program evaluation is the process of systematically determining the quality of a program and how it can be improved'. Evaluasi program adalah proses sistematis menentukan kualitas program dan upaya meningkatkan kualitas program tersebut.

\section{Simpulan}

Simpulan hasil penelitian ini adalah: (1) komponen penyelenggaraan UKK mencakup: (a) kolaborasi sekolah dengan asosiasi profesi dan DU/DI; (b) kinerja asesor; (c) sarana prasarana penunjang UKK; (d) sikap siswa terhadap UKK; (e) informasi capaian kompetensi siswa; dan (f) pengakuan legal asosiasi profesi dan DU/DI; (2) produk yang dikembangkan mencakup: instrumen evaluasi dan panduan penerapan instrumen. Sedangkan jenis instrumen evaluasi mencakup: (a) instrumen untuk responden siswa, dan (b) instrumen untuk responden guru; (3) hasil uji keterbacaan instrumen menunjukkan instrumen dalam kategori baik atau layak, rerata skor 3,92; (4) hasil analisis instrumen dengan responden siswa berdasarkan data uji coba pada tahap implementasi, seluruh instrumen valid (muatan faktor $>0,3$ dan nilai $t>1,96$ ), reliabel $(\alpha>0,7)$, dan memenuhi syarat sebagai model yang fit (RMSEA<0,08 dan GFI $>$ 0,90); (5) hasil analisis instrumen dengan responden guru pada tahap implementasi menunjukkan seluruh butir instrumen memiliki nilai validitas $>0,3$ dan memenuhi kriteria $K M O>0,5$ serta koefisien reliabilitas $\alpha>0,7$; (6) hasil uji panduan evaluasi berdasarkan penilaian pakar dan praktisi dianalisis secara diskriptif, mencapai rerata skor 3,99 berarti termasuk dalam klasifikasi layak digunakan; (7) instrumen evaluasi uji kompetensi keahlian yang dikembangkan memenuhi syarat validitas dan reliabilitas sehingga layak digunakan oleh pimpinan sekolah untuk mengevaluasi kualitas penyelenggaraan UKK Administrasi Perkantoran di SMK

\section{Saran}

Berdasarkan hasil penelitian ini dapat diajukan beberapa saran sebagai berikut: (1) instrumen yang dikembangkan dalam model ini hanya untuk responden siswa dan guru, belum melibatkan penilaian oleh pihak eks- 
ternal seperti asesor dan komite sekolah. Dengan demikian, disarankan kepada peneliti lain untuk dapat mengembangkannya lebih jauh, sehingga instrumen evaluasi IEUKK akan menjadi lebih baik; (2) cakupan objek penilaian dalam instrumen evaluasi IE-UKK, belum menjangkau komponen outcome yaitu kinerja para pemegang sertifikat kompetensi di dunia kerja. Oleh karena, itu disarankan kepada peneliti lain untuk mengembangkan instrumen evaluasi yang cakupannya sampai kepada komponen outcome UKK; (3) untuk meningkatkan efisiensi penerapan instrumen evaluasi IE-UK, pada produk pengembangan ini telah disusun soft file dalam Microsoft Office Excel, seorang evaluator disarankan memanfaatkan soft file tersebut sehingga menjadi lebih mudah dalam mengentri dan menganalisis data, serta menyusun rekomendasi hasil evaluasi dalam rangka perbaikan penyelenggaraan UKK ke depan.

\section{Daftar Pustaka}

Cox, J. (2006). The quality of an instructional program. National Education Association-Alaska. Diambil tanggal $23 \mathrm{Fe}-$ bruari 2009, dari http://www.ak.nea. org./excellence/coxquality

Crawford, D.C. (2006). "Suggestions to Assess Nonformal Education Programs" dalam ProQuest Education Journals.

Cullingford, C. (2000). Assessment versus evaluation. London. Cassell.

Direktorat Pembinaan SMK. (2009). Surat Edaran Direktorat Jenderal Manajemen Pendidikan Dasar dan Menengah Nomor: 351/C.C5/MN/2007 tentang Uji Kompetensi Keablian Kejuruan. Diambil tanggal 22 Mei 2008 dari http://209.85. 175.104/ditpsmk.net/ 2008 .

(2011). Petunjuk teknis pelaksanaan ujian kompetensi keablian SMK tahun pelajaran 2010/2011. Jakarta: Ditjen Pendidikan Menengah.
Djojonegoro, W. (1998). Pengembangan SDM melalui SMK. Jakarta: PT Jayakarta Agung Offset.

Fitzpatrick, J.L., Sanders, J.R., \& Worthen, B.R. (2011). Program evaluation alternative approaches and practical guidelines. Boston: Pearson.

Hair, J.F. et.al. (2010). Multivariate data analysis $7^{\text {th }}$ edition. New York: Pearson Prentice Hall

Ghozali, Imam. (2005). Structural equation modeling, Teori, konsep dan aplikasi dengan program Lisrel 8,80. Semarang: Badan Penerbit Universitas Diponegoro.

Johnson, B. \& Christensen, L. (2008). Educational research quantitative, qualitative, and mixed approaches. Los Angeles: SAGE Publications.

Mardapi, Djemari. (2005). Teknik penyusunan instrumen tes dan nontes. Yogyakarta: Mitra Cendikia Offset.

Mizikaci, F. (2007). A systems approach to program evaluation model for quality in higher education. ProQuest Education Journals. 130 (125-140).

Nurosis. (1986). SPSS/PC+for the imbbc/xt/ at. Chicago: SPSS Inc.

Royse, D., Thyer, B. \& Padgett, D., (2010). Program evaluation in introduction. Belmont: Wadsworth.

Sanders, J.R. \& Sullins, C.D. (2006). Evaluation school programs an educator's guide. California: Corwin Press.

Shavelson, R.J. (2001). Steps in designing an indicator system (versi elektronik). Practical assessment, research \& evaluation. Diambil tanggal 14 April 2013 dari http://PAREonline.net/getvn.asp?v $=2 \& n$.

Sigalingging, Karmon. (2009). Model evaluasi keativitas lomba kompetensi siswa SMK. Disertasi Doktor, tidak diterbitkan, Universitas Negeri Yogyakarta. 